\title{
PENGARUH STRATEGI PROMOSI DAN BRAND AWARENESS TERHADAP KEPUTUSAN PEMBELIAN FORE COFFEE DI CIPETE
}

\author{
Yanuar Wibisana \\ STIE Unisadhuguna Jakarta, Indonesia \\ Email : yanuar.wibisana@ubs-usg.ac.id
}

\begin{abstract}
Abstrak
Pendahuluan : Perkembangan kopi di Indonesia mengalami peningkatan yang cukup pesat setiap tahunnya. Awalnya, menikmati secangkir kopi menjadi hal biasa yang dilakukan oleh masyarakat Indonesia. Bahkan, masyarakat tidak terlalu mempedulikan bagaimana proses pembuatan kopi untuk menjadi secangkir minuman kopi, bahkan tidak peduli dengan masalah biaya.

Tujuan : Penelitian ini bertujuan untuk mengetahui apakah ada pengaruh Strategi Promosi dan Brand Awareness Terhadap Keputusan Pembelian di Fore Coffe Cipete. Metode : Penelitian ini dilakukan pada Agustus 2019 melalui bantuan Google Form (Online Questionnaire). Populasi dalam penelitian ini adalah konsumen Fore Coffe di wilayah Jakarta Selatan, khususnya di wilayah Cipete. Pengambilan sampel menggunakan purposive samplingtechniques. Data penelitian diperoleh melalui kuesioner online tentang strategi promosi dan brand awareness kepada 100 responden. Metode pengujian instrumen yang digunakan adalah validitas dan pengujian keandalan. Teknik analisis data yang digunakan adalah teknik deskriptif kuantitatif, analisis regresi linear dan t.

Hasil : Hasil penelitian menunjukkan bahwa dalam strategi promosi dan brand awareness fore coffe memiliki pengaruh pada keputusan pembelian.

Kesimpulan : Terdapat pengaruh positif dan signifikan antara strategi promosi dan brand awareness secara simultan terhadap keputusan pembelian di fore coffe cipete. Uji koefisien determinasi menghasilkan nilai 0,644 atau 64,4\% menunjukan bahwa variabel strategi promosi dan brand awareness berpengaruh pada keputusan pembelian di fore coffee.
\end{abstract}

Kata Kunci : strategipromosi; kesadaran merek; keputusan pembelian

\section{Abstract}

Introduction : The development of coffee in Indonesia has increased quite rapidly every year. Initially, enjoying a cup of coffee became a common thing done by the people of Indonesia. In fact, people do not really care how the process of making coffee to become a cup of coffee drink, not even concerned with the cost issue.

Purpose : This study aims to find out if there is an influence of Promotional Strategies and Brand Awareness on Purchasing Decisions at Fore Coffe Cipete.

Method : This research was conducted in August 2019 through the help of Google Form (Online Questionnaire). The population in this study was fore coffe consumers in the South Jakarta area, especially in the Cipete region. Sampling using purposive samplingtechniques. The research data was obtained through an online questionnaire about promotional strategies and brand awareness to 100 respondents. The instrument testing methods used are validity and reliability testing. The data analysis techniques used are quantitative descriptive techniques, linear regression analysis and $t$. 
Results : The results showed that in promotional strategies and brand awareness fore coffe has an influence on purchasing decisions.

Conclusion : There is a positive and significant influence between promotional strategies and brand awareness simultaneously on purchasing decisions in fore coffe cipete. The determination coefficient test resulting in a value of 0.644 or $64.4 \%$ shows that the variables of promotional strategy and brand awareness influence the purchasing decision in fore coffee.

Keywords: promotion strategy; brand awareness; and purchasing decisions

\section{Pendahuluan}

Perkembangan kopi di Indonesia mengalami peningkatan yang cukup pesat setiap tahunnya (Rafiah, 2020). Awalnya, menikmati secangkir kopi menjadi hal biasa yang dilakukan oleh masyarakat Indonesia. Bahkan, masyarakat tidak terlalu mempedulikan bagaimana proses pembuatan kopi untuk menjadi secangkir minuman kopi (Narulita, Winandi, \& Jahroh, 2014). Zaman berubah, dan zaman pada saat ini di sebut zaman millennial, bukan hanya sebuah zaman (Yin-Fah, Foon, Chee-Leong, \& Osman, 2010). Tapi, semua berubah. Dari ketertarikan akan hal biasa di jadikan suatu trend. Kopi menjadi trend yang sangat besar dan berdampak. Dari bagaimana proses pembuatan kopi menjadi secangkir kopi sampai bagaimana cara menikmati kopi secara baik dan trendy (Mardhotillah, 2013).

Brand startbucks dan the coffe bean\&tea leaf yang berasal dari amerika, memasuki pasar kopi Indonesia sejak tahun 2001 (Utama, 2012). Brand-brand ini menciptakan trend nya yang di terima oleh konsumen Indonesia. Sehingga, brand-brand ini tumbuh dengan sangat pesat dengan menciptakan trend dalam menikmati secangkir kopi. Proses bagaimana biji - bijian kopi menjadi secangkir minuman yang di inginkan konsumen adalah salah satu trend yang mereka ciptakan dan sangat di minati.

Munculnya brand--brand besar ini, menciptakan cara pandang yang berbeda dalam secangkir kopi. Gaya hidup, daya beli dan lingkungan sosial adalah cara pandang yang berdampak besar pada ingatan calon konsumen atau konsumen (Kheyene, 2013).

Trend ini berjalan dengan baik, sejak masuknya beberapa brand-brand besar ke pasar kopi Indonesia. Akan tetapi, kondisi ini tidak menunjukan kondisi baik di pasar kopi Indonesia. Konsumsi pada kopi mengalami keadaan tidak stabil. Serta, mengarah pada grafik penurunan dari beberapa tahun terakhir (Alexander \& Nadapdap, 2019).

Hasil Survei Sosial Ekonomi Nasional (SUSENAS) yang dilakukan Badan Pusat Statistik menunjukkan bahwa konsumsi kopi/kapita rumah tangga mengalami trend penurunan, walau sempat ada kenaikan yang cukup meningkat di tahun 2013 dan mengalami penurunan kembali ditahun berikutnya (Ulyah, 2019).

Kemunculan brand luar negeri membuat konsumen mulai menginginkan inovasi lainnya yang akan muncul. Konsumen sudah mulai mengerti dan belajar, akan hal yang mereka minati dari kopi yang di jual oleh brand - brand besar tersebut. Daya beli lebih menjadi perhatian yang diinginkan konsumen selain tuntutan gaya hidup. 
Peluang ini yang diambil oleh banyak calon-calon pengusaha yang memasukin pasar kopi Indonesia. banyaknya brand lokal yang mulai muncul yang menciptakan, apa yang sudah ditawarkan oleh brand - brand besar selama ini. Dengan sedikit perbedaan dari mengambil peluang akan daya beli masyarakat.

Menurut (As' ad \& Aji, 2020) pengaruh banyaknya brand kedai kopi lokal yang muncul di pasar kopi Indonesia. membuat peningkatan yang signifikan pada konsumsi kopi di Indonesia. Mulai menjamurnya kedai kopi memberikan dampak positif untuk pasar kopi Indonesia. Kenaikan ini diprediksi akan mengalami kenaikan sampai pada tahun 2021. Faktor dari kenaikan ini juga adalah keinginan lain yang diinginkan oleh konsumen pada brand - brand luar ataupun brand-brand local pada pasar kopi dalam berinovasi selain mempermudah dalam bertransaksi serta keinginan lainnya (Haryantini \& Sadya, 2018).

Keinginan para konsumen dan calon konsumen yang terus bertambah menjadi target market selanjutnya dalam peningkatan inovasi baru yang akan di ambil oleh para brand kopi luar dan brand kopi lokal. Akan tetapi, inovasi ini yang menjadikan penurunan inovasi. Banyaknya brand luar dan brand lokal dalam menggunakan konsep strategi "red ocean" menjadikan kebingungan konsumen. Karena menurut (Sintha, 2013) red ocean merupakan persaingan pasar yang konvesional (yang sudah ada).

Namun, pada bulan agustus tahun 2018, kemunculan salah satu brand baru lokal menarik minat dikalangan calon konsumen. Fore coffee adalah start-up bermodel bisnis kedai kopi. Fore coffee hadir dengan gagasan yang inovatif pada konsep yang tawarkan-nya.

Fore coffee melakukan promosi dengan konsep advertensi elektronik melalui platform sosial media untuk menciptakan kesadaran merek (brand awareness), selain itu fore coffe adalah perusahaan start-up yang memiliki aplikasi sendiri, fore melakukan promosi dengan konsep customer experience.

Cara ini dapat menarik perhatianpara konsumen. Menurut (Hariyadi, 2021) promosi adalah kegiatan penjualan dan pemasaran dalam rangka menginformasikan dan mendorong permintaan terhadap produk, jasa, dan ide perusahaan dengan cara mempengaruhi konsumen agar mau membeli produk atau jasa yang dihasilkan oleh perusahaan. Dengan promosi ini fore coffe mengharapkan konsumen mengenali, mengingat dan tertarik akan apa yang ditawarkan fore coffe.

Fore coffee membuat kesadaran merek (brand awareness) pada konsumen. Karena kesadaran merek (brand awareness) berperan penting dalam mempengaruhi keputusan pembelian konsumen (Purnomo, 2018). Dengan menampilkan promosi advertensi elektronik di platform media sosial dapat memberikan kesadaran merek (brand awareness) pada konsumen .

Dengan ditambahnya customer experince, konsumen bisa lebih dapat mengingat akan produk fore coffe dan dapat mempengaruhi keputusan pembelian konsumen (Ailudin \& Sari, 2019). Customer experience yang dipakai oleh fore coffee adalah memberikan kopi gratis tanpa batas jangka waktu dalam promosinya (Senjaya, 2013). Dengan cara yang mudah untuk mendapatkan kopi gratis, yaitu dengan mengunduh 
aplikasi milik fore coffee. Bukan hanya satu gelas kopi gratis yang di tawarkan oleh fore coffe. Tapi, tanpa batas dengan syarat mengajak orang sekitar mengunduh aplikasi fore coffee dengan menggunakan kode milik pelanggan yang sudah pernah membeli kopi di fore coffe.

Adapun tujuan dari penelitian ini adalah untuk mengetahui apakah ada hubungan pengaruh strategi promosi secara parsial pada keputusan pembeli, kesadaran merek (brand awareness) secara parsial pada keputusan pembeli, serta hubungan strategi promosi dan kesadaran merek (brand awareness) secara simultan pada keputusan pembeli di fore coffe.

\section{Metode Penelitian}

Populasi dalam penelitian ini adalah pengunjung atau konsumen Fore Coffe di Cipete dimana jumlahnya adalah 100 orang. Teknik sampling yang digunakan adalah simple random sampling.

Teknik pengumpulan data dalam penelitian ini dilakukan dengan 2 (dua) cara, yaitu dengan menyebarkan kuesioner (daftar pertanyaan) kepada para konsumen Fore Coffe Cipete dengan harapan dapat memberikan respon terhadap daftar pertanyaan tersebut (Suliyanto \& MM, 2017). Kuesioner disusun menggunakan skala likert. Pengumpulan data berikutnya dilakukan mengadakan studi penelaahan terhadap bukubuku, litertur-literatur, catatan-catatan, dan laporan-laporan yang ada hubungannya dengan masalah yang dipecahkan (Rukajat, 2018).

Setelah data-data yang diperlukan didapat, langkah selanjutnya adalah dengan melakukan uji instrumen. Dalam langkah ini dilakukan dalam 2 (dua) tahap pengujian, yaitu uji validitas dan uji reliabilitas. Untuk menguji validitas kuesioner digunakan rumus korelasi Product Moment Pearson. Sedangkan uji reliabilitas menggunakan alat ukur dengan rumus Alpha Cronbach (Sugiyono, 2016). Dengan Interpretasi koefisien Korelasi r sebagai berikut (Sugiyono, 2016).

Tabel 1

Interpretasi Koefisien Korelasi Nilai $\mathbf{r}$

\begin{tabular}{ll}
\hline Interval Koefisien & Tingkat Hubungan \\
\hline $0,80-1,000$ & Sangat Kuat \\
$0,60-0,799$ & Kuat \\
$0,40-0.599$ & Cukup Kuat \\
$0,20-0,399$ & Rendah \\
$0,00-0,199$ & Sangat Rendah \\
\hline
\end{tabular}

Uji asumsi klasik dalam penelitian ini di lakukan dalam 3 (tiga) pengujian, yaitu: normality test, multicoliinierity test, dan heteroscedasticity test (Arikunto, 2016). Normality test menggunakan metode Kolmogorov smirnov. Multicoliinierity test dilakukan dengan cara menghitung nilai Variance Inflation Factor (VIF) terhadap semua variabel bebasnya. Terjadi multikolinearitas jika nilai VIF > 10,00. Jika nilai VIF $<$ 10,00 korelasi antar variabel bebasnya masih dapat ditolerir (Sugiyono, 2016). Sedangkan uji heteroskedastisitas menggunakan metode Glejser. 
Pengujian berikutnya adalah pengujian parameter, meliputi uji parameter individual (uji statistik t) bertujuan untuk mengukur seberapa jauh pengaruh satu variabel independen secara individual dalam menerangkan variasi variabel dependen dan uji parameter secara simultan. Dan yang terakhir adalah pengujian best of fit model.

\section{Hasil dan Pembahasan}

Penelitian yang menggunakan kuesioner / angket, terlebih dahulu harus dilakukan uji instrumen, yang terdiri dari:

1. Uji Validitas

Hasil uji validitas variabel Strategi Promosi dapat dilihat pada Tabel 2

Tabel 2

Hasil Uji Validitas Variabel Strategi Promosi (X1)

\begin{tabular}{cccc}
\hline Pernyataan & R hitung & R tabel & Keterangan \\
\hline $\mathrm{X} 1$ & 0,498 & 0,195 & Valid \\
\hline $\mathrm{X} 2$ & 0,537 & 0,195 & Valid \\
\hline $\mathrm{X} 3$ & 0,617 & 0,195 & Valid \\
\hline X4 & 0,611 & 0,195 & Valid \\
\hline X5 & 0,431 & 0,195 & Valid \\
\hline X6 & 0,513 & 0,195 & Valid \\
\hline
\end{tabular}

Dari Tabel 2 di atas dapat dilihat bahwa untuk masing-masing pernyataan pada variabel strategi promosi (X1) seluruh instrument dapat dikatakan valid, karena nilai rhitung yang dihasilkan lebih besar dari pada nilai rtabel. Untuk hasil uji validitas variabel Brand awarness dapat dilihat pada Tabel 3

Tabel 3

Hasil Uji Validitas Variabel Brand Awareness (X2)

\begin{tabular}{cccc}
\hline Pernyataan & Rhitung & Rtabel & Keterangan \\
\hline $\mathrm{X} 2.1$ & 0,660 & 0,195 & Valid \\
\hline $\mathrm{X} 2.2$ & 0,735 & 0,195 & Valid \\
\hline $\mathrm{X} 2.3$ & 0,849 & 0,195 & Valid \\
\hline X2.4 & 0,843 & 0,195 & Valid \\
\hline
\end{tabular}

Sumber : Data diolah

Berdasarkan Tabel 3 di atas, dapat dilihat bahwa untuk masing-masing pernyataan pada variabel brand awarness (X2) seluruh instrument dapat dikatakan valid, karena nilai $r$ hitung yang dihasilkan lebih besar dari pada nilai $r$ tabel.

Sedangkan hasil uji validitas variabel keputusan membeli (Y) dari sampel berjumlah 100 (seratus) dengan jumlah pernyataan sebanyak 6 (enam) dapat dilihat pada Tabel 4 .

Tabel 4

Hasil Uji Validitas Variabel Keputusan Pembelian (Y)

\begin{tabular}{cccc}
\hline Pernyataan & Rhitung & Rtabel & Keterangan \\
\hline Y1 & 0,284 & 0,195 & Valid \\
\hline Y2 & 0,880 & 0,195 & Valid \\
\hline Y3 & 0,863 & 0,195 & Valid \\
\hline Y4 & 0,842 & 0,195 & Valid
\end{tabular}




\begin{tabular}{cccc}
\hline Y5 & 0,830 & 0,195 & Valid \\
\hline Y6 & 0,903 & 0,195 & Valid \\
\hline
\end{tabular}

Sumber : Data diolah

Berdasarkan Tabel 4 di atas, dapat dilihat bahwa untuk masing-masing pernyataan pada variabel Keputusan Pembelian (Y) seluruh instrument dapat dikatakan valid, karena nilai rhitung yang dihasilkan jauh lebih besar dari pada nilai rtabel yang ada untuk $\mathrm{n}=100$ (seratus) yaitu 0.195 .

2. Uji Reliabilitas

Hasil penelitian menunjukan bahwa semua variabel penelitian reliabel. Hal ini ditunjukkan pada Tabel 5

Tabel 5

Hasil Uji Reliabilitas Variabel-variabel Penelitian

\begin{tabular}{cccc}
\hline $\begin{array}{c}\text { Varibel } \\
\text { Instrumen }\end{array}$ & $\begin{array}{c}\text { Cronbach's } \\
\text { Alpha }\end{array}$ & Keterangan & Kategorisasi \\
\hline $\begin{array}{c}\text { Strategi promosi } \\
\left(\mathrm{X}_{1}\right)\end{array}$ & 0,689 & Reliabel & Cukup \\
\hline $\begin{array}{c}\text { Brand Awarness } \\
\left(\mathrm{X}_{2}\right)\end{array}$ & 0,750 & Reliabel & Kuat \\
\hline $\begin{array}{c}\text { Keputusan } \\
\text { Pembelian }(\mathrm{Y})\end{array}$ & 0,874 & Reliabel & Sangat Kuat \\
\hline
\end{tabular}

Sumber : Data diolah

3. Uji Asumsi Klasik

Model regresi yang baik, harus memenuhi asumsi BLUE, yaitu Best LinearUnbiased Estimator.

1) Uji Normalitas

Uji normalitas digunakan untuk menguji apakah model regresi mempunyai distribusi normal ataukah tidak. Asumsi normalitas merupakan persyaratan yang sangat penting pada pengujian kebermaknaan (signifikansi) koefisien regresi. Model regresi yang baik adalah model regresi yang memiliki distribusi normal atau mendekati normal, sehingga layak dilakukan pengujian secara statistik.

Pengujian normalitas pada penelitian ini menggunakan metode P-Plot Diagram. Jika titik-titik hasil observasi berada disekitar garis predictor, dapat dikatakan bahwa data berdistribusi normal.

Hasil uji normalitas data penelitian ini dapat dilihat pada Gambar 1 berikut. 


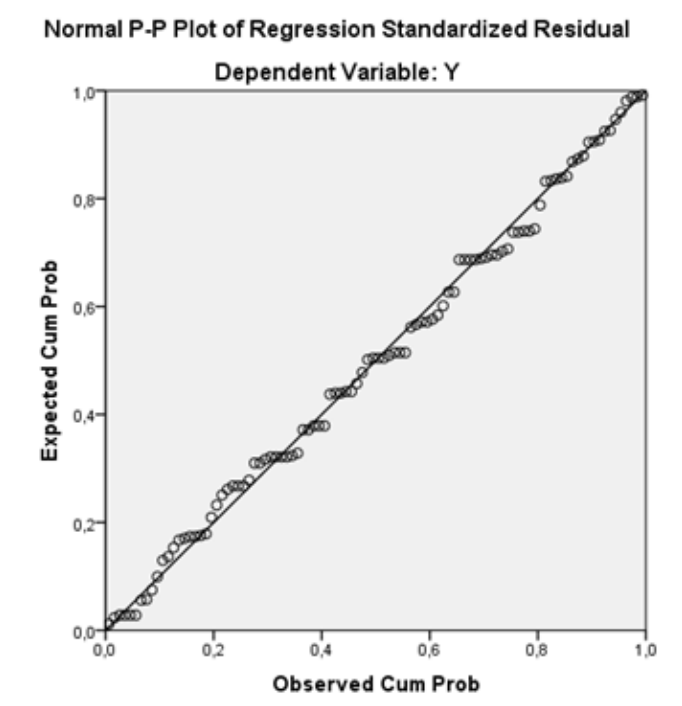

Gambar 1

Hasil Uji Normalitas Menggunakan Metode P-Plot Diagram

Sumber: Data diolaher : data diolah

Berdasarkan hasil pengujian normalitas pada Gambar 1, dapat disimpulkan bahwa data berdistribusi normal, karena titik-titik hasil observasi berada di sekitar garis prediktornya.

2) Uji Multikolinearitas

Uji multikolinearitas bertujuan untuk mengetahui apakah terdapat hubungan yang kuat antar variabel independen. Di dalam penelitian ini uji multikolinearitas menggunakan nilai VIF dan tolerance. Hasil yang didapat disajikan pada Tabel 6

Tabel 6.

Hasil Uji Multikolinearitas

\begin{tabular}{lllll}
\hline No & Variabel & Tolerance & VIF & Keterangan \\
\hline 1 & $\begin{array}{l}\text { Strategi Promosi } \\
\left(\mathrm{X}_{1}\right)\end{array}$ & 0.967 & 1.035 & Bebas multikolinearitas \\
\hline 2 & $\begin{array}{l}\text { Brand Awareness } \\
\left(\mathrm{X}_{2}\right)\end{array}$ & 0.967 & 1.035 & Bebas multikolinearitas \\
\hline
\end{tabular}

Sumber : Data diolah

Berdasarkan tabel 6 menunjukkan nilai tolerance untuk semua variabel independen lebih besar dari 0,1 dan nilai VIF kurang dari 10, maka dapat disimpulkan bahwa variabel independen bebas multikolinearitas.

3) Uji Heterokedastisitas

Uji heteroskedastisitas bertujuan untuk menguji apakah di dalam model regresi terjadi ketidaksamaan variasi dari data pengamatan yang satu ke pengamatan yang lain. Salah satu cara untuk mendeteksi heteroskedastisitas ini adalah dengan melihat pola sebaran pada grafik scatter plot. Jika ada pola tertentu seperti titik-titik yang ada membentuk pola tertentu yang teratur maka 
mengindikasikan telah terjadi heteroskedastisitas dan jika tidak ada pola yang jelas serta titik-titik menyebar di atas dan di bawah angka 0 pada sumbu Y maka tidak terjadi heteroskedastisitas Ghozali, (2005:297).

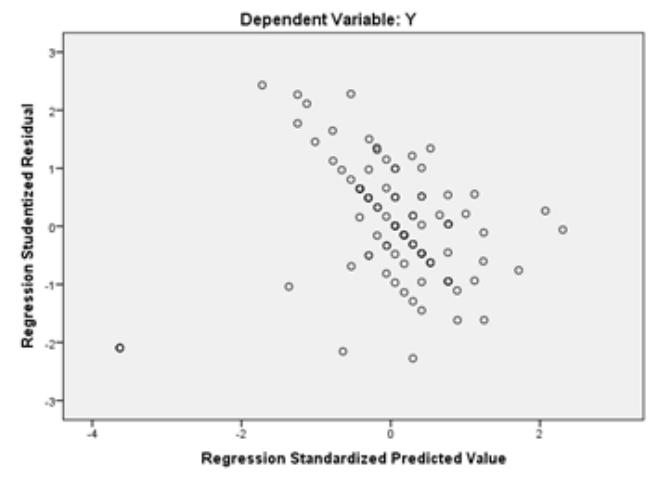

Gambar 2. Hasil Uji Heteroskedastisitas Sumber : Data diolah

Dari Gambar 2 di atas terlihat bahwa titik-titik observasi berada di sekitar titik nol dan tidak membentuk suatu pola tertentu. Sehingga dapat disimpulkan bahwa tidak terjadi gejala heteroskedastisitas dalam model.

4) Uji Individual dan Uji Simultan

Pengujian selanjutnya adalah uji hipotesis. Uji Hipotesis pada penelitian ini dilakukan dalam 2 (dua) pengujian, yaitu:

a. Uji t dan Uji F

Uji t dilakukan untuk menentukan apakah variable-variabel independen secara parsial berhubungan terhadap variable dependennya. Adapun hasilnya terlihat pada table 7

Tabel 7 Hasil Uji t dan Uji F

\begin{tabular}{cccc}
\hline Variabel & $\begin{array}{c}\text { Koefisien } \\
\text { Regresi } \\
(\mathbf{B})\end{array}$ & t hitung & Sig \\
\hline $\begin{array}{c}\text { Strategi } \\
\text { promosi }\end{array}$ & 0.320 & 3.662 & 0,000 \\
\hline $\begin{array}{c}\text { Brand } \\
\text { Awareness }\end{array}$ & 0.974 & 11.854 & 0,000 \\
\hline \multicolumn{3}{c}{ Fhit $=87.828$} & 0.000 \\
\hline \multicolumn{3}{c}{ Sumber : Data Diolah }
\end{tabular}

Hasil penelitian menunjukan nilai t hitung pada variabel strategi promosi sebesar 0.320 dengan nilai sig sebesar 0,000. Kriteria keputusan tolak Ho jika t hitung > t tabel atau sig < taraf kesalahan. Dari hasil penelitian dapat diketahui $\mathrm{t}$ hitung $=3.662$ yang artinya lebih besar dari t tabel $=2,0281$ atau sig $=0,000$ < taraf kesalahan 5\% maka dapat disimpulkan bahwa strategi promosi yang digunakan berpengaruh positif terhadap keputusan membeli. Hal ini ditunjukkan dari nilai koefisien regresi yang dihasilkan bertanda positif yaitu sebesar 0.320 . 
Hasil penelitian menunjukan bahwa nilai $\mathrm{t}$ hitung variabel brand awareness sebesar 11.854 dengan nilai sig sebesar 0,000. Kriteria keputusan tolak Ho jika $\mathrm{t}$ hitung > $\mathrm{t}$ tabel atau sig < taraf kesalahan, maka dari hasil penelitian dapat diketahui t hitung $=11.854$ yang lebih besar dari nilai t tabel sebesar 2,081. Maka dapat disimpulkan bahwa strategi promosi berpengaruh positif terhadap keputusan membeli.

Strategi promosi dan brand awarnesssecara bersama-sama berpengaruh terhadap keputusan membeli. Hal ini dapat dilihat dari nilai $\mathrm{F}$ hitung sebesar 87.828 dengan nilai sig $=0,000$. Sedangkan nilai $F$ table sebesar 3,505 pada tingkat kesalahan 5\%. Sehingga dapat disimpulkan bahwa terdapat pengaruh secara simultan antara strategi promosi dan brand awareness terhadap keputusan membeli.

b. Koefisien Determinasi

Hasil penelitian menunjukan nilai R2 sebesar 0.644, artinya bahwa variable strategi promosi dan variable brand awareness secara bersama-sama mampu menjelaskan variabel keputusan membeli sebesar 64,4\% dan 35,6\% adalah hal lain yang tidak menjadi bagian penelitian ini.

a) Analisis dan Persamaan Regresi Linear Berganda

Dari Tabel 7, didapat persamaan regresi linear berganda sebagai berikut:

$\mathrm{Y}=1,349+0,320 \mathrm{X} 1+0,974 \mathrm{X} 2$

Dimana:

$\mathrm{X} 1$ : Strategi promosi

X2: Brand Awareness

Y : Keputusan membeli

Dapat dijelaskan sebagai berikut:

1. Nilai konstanta intersep sebesar 1,349 menyatakan bahwa jika variabel strategi promosi (X1) dan variabel brand awareness (X2) bernilai nol maka nilai variabel keputusan membeli (Y) adalah sebesar 1,349.

2. Nilai koefisien regresi variabel strategi promosi (X1) terhadap variabel keputusan membeli (Y) adalah sebesar 0.320. Hal ini berarti jika variabel strategi promosi (X1) naik 1 satuan akan meningkatkan variabel keputusan membeli (Y) sebesar 0.320, dengan asumsi variabel brand awareness (X2) dan konstanta tetap. Pengertian strategi promosi penjualan adalah perencanaan aktivitas yang dilaksanakan dalam rangka peningkatan permintaan dari para konsumen untuk meningkatkan volume dan omset penjualan. Aktivitas tersebut dilakukan dengan mempengaruhi secara langsung konsumen dalam keputusan pembelian.

3. Nilai koefisien regresi variabel brand awareness (X2) terhadap variabel keputusan membeli (Y) adalah sebesar 0.974. Hal ini berarti jika variabel brand awareness (X2) naik 1 satuan akan meningkatkan variabel keputusan membeli (Y) sebesar 0.974, dengan asumsi variabel strategi promosi (X1) dan konstanta tetap. Menurut Keller (2004) pada penelitian 
Putri (2013:24) brand awareness terdiri dari pengenalan sebuah merek dan mengingat kembali sebuah merek. Dimana pengenalan sebuah merek berkaitan dengan kemampuan konsumen dalam menguatkan pengertian sebelumnya tentang sebuah merek sebagai petunjuk, dapat ditambahkan bahwa mengharuskan konsumen dalam membedakan merek yang sebelumnya telah dilihat atau didengar.

\section{Kesimpulan}

Berdasarkan hasil analisis makan diperoleh kesimpulan bahwasanya terdapat pengaruh yang signifikan pada strategi promosi terhadap keputusan pembelian di fore coffe cipete. Berdasarkan hasil pengujian persial pengaruh strategi promosi terhadap keputusan pembelian diperoleh thitung 3,662 > ttabel 1,987 dengan taraf signifikan $0,000<0,05$ nilai 3,662 > dari 1,987 menunjukan thitung lebih besar dari ttabel.hal ini menunjukan bahwa ada pengaruh yang signifikan antara strategi promosi terhadp keputusan pembelian.

Terdapat pengaruh yang signifikan pada brand awareness terhadap keputusan pembelian di fore coffee cipete. Berdasarkan hasil pengujian persial pengaruh brand awareness terhadap keputusan pembelian diperoleh thitung 11,854 > tabel 1,987 dengan taraf signifikan $0,000<0,05$ nilai $11,854>$ dari 1,987 menunjukan thitung lebih besar dari t tabel. Hal ini menunjukan bahwa ada pengaruh yang signifikan antara strategi promosi terhadap keputusan pembelian.

Terdapat pengaruh positif dan signifikan antara strategi promosi dan brand awareness secara simultan terhadap keputusan pembelian di fore coffe cipete. Uji koefisien determinasi menghasilkan nilai 0,644 atau 64,4\% menunjukan bahwa variabel strategi promosi dan brand awareness berpengaruh pada keputusan pembelian di fore coffee. 
Pengaruh Strategi Promosi dan Brand Awareness terhadap Keputusan Pembelian Fore Coffee

Di Cipete

\section{DAFTAR PUSTAKA}

Ailudin, Mardian, \& Sari, Devilia. (2019). Pengaruh Customer Experience Terhadap Minat Beli Ulang (studi Pada Pelanggan One Eighty Coffee Bandung). EProceedings of Management, 6(1).

Alexander, Ivan, \& Nadapdap, Hendrik Johannes. (2019). Analisis Daya Saing Ekspor Biji Kopi Indonesia di Pasar Global Tahun 2002-2017. JSEP (Journal of Social and Agricultural Economics), 12(2), 1-16.

As' ad, Mochamad Hafezd, \& Aji, Joni Murti Mulyo. (2020). Faktor Yang Mempengaruhi Preferensi Konsumen Kedai Kopi Modern Di Bondowoso. Jurnal Sosial Ekonomi Pertanian (J-SEP), 13(2), 182-199.

Hariyadi, Tutut. (2021). Pengaruh Kualitas Produk, Harga, dan Promosi Terhadap Keputusan Pembelian Powder Drink Pada Jakarta Powder Supply (JPS) Cabang Banyuwangi. Ekonomi, Keuangan, Investasi Dan Syariah (EKUITAS), 3(2), 235238.

Haryantini, H., \& Sadya, Agra. (2018). Sistem Informasi Pemasaran.

Kheyene, Molekandella Boer. (2013). Representasi Starbucks Sebagai Gaya Hidup Konsumerisme [Monolog Kebudayaan Barat Kepada Timur Dalam Secangkir Kopi]. Master Program in Communication Science.

Mardhotillah, Izzati Choirini. (2013). pengaruh kualitas layanan terhadap keputusan pembelian konsumen di baseball food court Universitas Negeri Surabaya. Jurnal Universitas Negeri Surabaya, 1-16.

Narulita, Sari, Winandi, Ratna, \& Jahroh, Siti. (2014). Analisis dayasaing dan strategi pengembangan agribisnis kopi Indonesia. Jurnal Agribisnis Indonesia (Journal of Indonesian Agribusiness), 2(1), 63-74.

Purnomo, Terrius. (2018). Pengaruh kesadaran merek dan citra merek terhadap niat beli pada konsumen herbalife di surabaya. Agora, 6(1).

Rafiah, Kurnia Khafidhatur. (2020). Review Strategi Pemasaran Efektif Untuk UMKM Kedai Kopi Dalam menghadapi Masa Pandemi. Jurnal Ekonomi Dan Bisnis Terapan, 16(2), 30-38.

Rukajat, Ajat. (2018). Pendekatan penelitian kuantitatif: quantitative research approach. Deepublish.

Senjaya, Vivie. (2013). Pengaruh customer experience quality terhadap customer satisfaction \& customer loyalty di kafe excelso tunjungan plaza surabaya: perspektif b2c. Jurnal Strategi Pemasaran, 1(1).

Sintha, Lis. (2013). BLUE OCEAN vs RED OCEAN. JURNAL KEUANGAN DAN PERBANKAN, 1(1), 46-66.

Sugiyono. (2016). Metode Penelitian Pendidikan. Bandung: Alfabeta CV.

Suliyanto, S. E., \& MM, Suliyanto. (2017). Metode Penelitian Kuantitatif.

Ulyah, Izzatul. (2019). Pengaruh Gaya Hidup dan Kelompok Acuan terhadap Keputusan Pembelian dengan Pendapatan sebagai Variabel Pemoderasi pada Konsumen Warkop Radja di Kabupaten Gowa. Universitas Islam Negeri Alauddin Makassar.

Utama, Aria Waskita. (2012). Analisis Pengaruh Customer Emotion, Citra Merek, Dan Harga Terhadap Loyalitas Pelanggan Starbucks Jakarta. STIE Indonesia Banking School. 
Yin-Fah, Benjamin Chan, Foon, Yeoh Sok, Chee-Leong, Lim, \& Osman, Syuhaily. (2010). An exploratory study on turnover intention among private sector employees. International Journal of Business and Management, 5(8), 57. 